\title{
Habitat use and conservation status of two elusive ground birds (Carpococcyx radiatus and Polyplectron schleiermacheri) in the Sungai Wain Protection Forest, East Kalimantan, Indonesian Borneo
}

\author{
Gabriella M. Fredriksson and Vincent Nijman
}

\begin{abstract}
We studied the distribution and habitat-use of two endemic ground birds, the Bornean groundcuckoo Carpococcyx radiatus and the Bornean peacockpheasant Polyplectron schleiermacheri in the Sungai Wain Protection Forest, East Kalimantan. Both species are highly elusive and neither has been subject to any in-depth study. Consequently, few data are available on their population numbers, habitat preferences and conservation status. We mapped the species' presence in five topographical habitat types, assessed their spatial distribution, and provide an estimate of population sizes in the reserve. Over a period of 44 months (1997-2003) we had 32 encounters with Bornean ground-cuckoo, and 19 encounters with Bornean peacock-pheasant. Number of encounters increased over time, but no seasonal or monthly difference was apparent in encounter rate. Both species were only observed inside the central core of the reserve. Bornean ground-cuckoo showed a clear
\end{abstract}

preference for alluvial and swamp forest over highflat, slope and ridge forest. Bornean peacock-pheasant showed no clear preference for any of these five habitat types. Considering the rapid destruction of forest occurring in Kalimantan due to illegal logging, fires, lack of law enforcement and proper management of protected areas, the conservation of these two species is discussed in relation to conservation management of the Sungai Wain Protection Forest. Teams are patrolling year-round in the reserve to halt hunting. Illegal logging has been eradicated by these patrols, in combination with treespiking. Fire breaks are maintained each dry season to avoid further fire damage, and extensive education and awareness work is carried out in the district.

Keywords Bornean ground-cuckoo, Bornean peacockpheasant, Carpococcyx radiatus, forest, Indonesia, Kalimantan, Polyplectron schleiermacheri.

\section{Introduction}

The Bornean ground-cuckoo Carpococcyx radiatus and Bornean peacock-pheasant Polyplectron schleiermacheri are terrestrial forest birds endemic to the island of Borneo. The Bornean ground-cuckoo is a large $(60 \mathrm{~cm})$ bird, with a purple-glossed black head, the mantle and back green with purple gloss and coppery-red reflections, wing and tail unbarred coppery-violet, underparts barred white and black, with the bare skin around the eye green. The Bornean peacock pheasant is a medium-sized pheasant with a pure white throat and breast, surrounded by a metallic blue-green rim. Facial skin is orange, and stunning blue-green ocelli cover the entire mantle and tail. Despite their striking appearances, both species are highly inconspicuous and relatively little data is available on their biology and conservation status

Gabriella M. Fredriksson (Corresponding author) and Vincent Nijman Institute for Biodiversity and Ecosystem Dynamics / Zoological Museum, University of Amsterdam, P.O. Box 94766, 1090 GT Amsterdam, The Netherlands. E-mail gmfred@indo.net.id

Received 28 May 2003. Revision requested 5 November 2003. Accepted 19 January 2004.
(Holmes \& Burton, 1987; Laman et al., 1997; O’Brien et al., 1998; Collar et al., 2001; Long \& Collar, 2002).

The Bornean ground-cuckoo is categorized as Lower Risk: near threatened and the Bornean peacock-pheasant as Endangered on the IUCN Red List (Collar et al., 2001; IUCN, 2003), with most of the confirmed records concentrated in the central part of the island. From the scant data available it seems that both species are generally confined to the low-lying forest below $500 \mathrm{~m}$ altitude, a habitat that once covered a considerable part of the island. Over the last decade, however, the decrease of lowland forest on Borneo, and especially alluvial forest, has been dramatic. It has been suggested that this habitat type will have been lost to logging, plantation development and forest fires by the end of this decade (Jepson et al., 2001). The impact of uncontrolled forest fires is especially severe, with millions of hectares of forested land affected over the last decades (Siegert et al., 2001). For effective conservation of the Bornean ground-cuckoo and the Bornean peacock-pheasant it is of utmost importance to gain greater insight into their habitat preferences and how to effectively manage forest areas for their requirements. The aim of this paper is to document the 
occurrence and habitat use of Bornean ground-cuckoo and Bornean peacock-pheasant in the Sungai Wain Protection Forest, East Kalimantan and, based on this, to report on the threats both species face in the Forest and Borneo as a whole.

\section{Study area}

The Sungai Wain Protection Forest is a water-catchment reserve of $c .100 \mathrm{~km}^{2}$, near Balikpapan, East Kalimantan (Fig. 1). It is one of the last remaining primary coastal lowland forests in East Kalimantan. Relative to its size, it harbours a large number of globally threatened species, including Wallace's hawk-eagle Spizaetus nanus, clouded leopard Neofelis nebulosa, proboscis monkey Nasalis larvatus, and a small population of reintroduced Bornean orang-utans Pongo pygmaeus. Three-quarters of the reserve are covered with lowland dipterocarp rain forest and the reserve has become isolated from other forest areas in recent years. The topography of the reserve consists of gentle to steep hills intersected by small rivers (Fredriksson \& de Kam, 1999).

In 1998 c. $60 \%$ of the reserve was affected by forest fires (Fredriksson, 2002), mainly in the undergrowth. A man-made fire break prevented the fires from entering the central core area. Currently the Sungai Wain Protection Forest consists of c. $40 \mathrm{~km}^{2}$ of primary forest, $40 \mathrm{~km}^{2}$ of regenerating burned forest, and $20 \mathrm{~km}^{2}$ affected by



Fig. 1 Location of the Sungai Wain Protection Forest in East Kalimantan, Indonesia, and the burnt and unburnt areas of the Forest. encroachment. Average annual rainfall in the reserve (1998-2002) is $2,968 \pm 510 \mathrm{~mm}$. Although rainfall patterns are not consistent on an annual basis, a distinction can be made between the wet and dry season, with the wettest time being December-March and the driest August-November.

\section{Methods}

\section{Data collection}

We worked in the Sungai Wain Protection Forest during 1997-2003 (GMF) and intermittently between 1999-2002 (VN), and a total of 44 months of fieldwork were conducted in the northern part of the reserve. Data were collected along a trail system with $152-\mathrm{km}$ transects spaced $250 \mathrm{~m}$ apart running east-west, and three 7-km transects $500 \mathrm{~m}$ apart running north-south. Additionally, a number of trails following geographical features run through the forest, enabling us to traverse the entire northern part of the reserve, with approximate equal coverage of all sections. While independently conducting research on sun bears Helarctos malayanus and primates, observations of Bornean ground-cuckoo and Bornean peacock-pheasant were geo-referenced on a 1:11,000 scale map. Each record was assigned to a habitat category (see below). Birds were recorded visually and aurally, although in the later stages of the study, once we had become familiar with the different vocalizations, most data were collected aurally, with first calling position geo-referenced (Bibby et al., 1992). Both species have a large range of vocalizations, many of which have only recently been recognized (Collar et al., 2001; Long \& Collar, 2002; S. van Balen, R. Sözer, pers. comm.). Most of the Bornean ground-cuckoo vocalizations we heard are described in detail by Long \& Collar (2002), although we do not always share their interpretation of the function of the calls. The vocalization of Bornean peacock-peasant has been described as a harsh loud double 'cack-cack' ( $R$. Sözer, pers. comm.), occasionally also uttered as a single loud 'cack' or as a tripartite with a deflecting last note.

\section{Habitat classifications}

We classified five different topographical types in the forest: alluvial, swamp, slope, high-flat and ridge. Alluvial forest is defined as a flat non-inundated area close to rivers and is characterized by large trees. Swamp forest is defined as an area that is inundated and/or shows signs of regular inundation (pneumatophore roots) and is characterized by a high density of rattans, small diameter trees, and a large numbers of climbers. High-flat forest is defined as a flat area at an elevated site away from rivers, usually characterized by large trees. Slope forest 
is defined as an area with a relatively steep $\left(>12^{\circ}\right)$ inclination. Ridge forest is defined as the narrow tops of hills with steep sides or crests of longer hill chains. In the unburned forest we recorded these topographical types at every $25 \mathrm{~m}$ along the transect system. Within the burned forest a matrix of small patches of unburned forest remains. Along an extension of the transect system (three transects of $2 \mathrm{~km}$ ) into the burned forest, we recorded at every $50 \mathrm{~m}$ whether or not the forest was actually burnt.

\section{Analysis}

Annual and seasonal variation in the abundance of both species and variation in their detectability was tested by comparing monthly encounter rates (i.e. the number of records per month) using a one-way Kruskal-Wallis analysis of variance with years or months as samples (Siegel, 1956). For analysis the year was divided into three 4-month intervals, representing wet (DecemberMarch), intermediate (April-July) and dry (AugustNovember) periods. During our study we considered both species to be relatively sedentary, based on repeated visual and aural observations at certain locations. For instance, near our base-camp calls of the Bornean ground-cuckoo could be heard daily during certain periods of our study, and Bornean peacock-pheasant was both irregularly seen and heard at approximately the same location over a period of several years. As multiple records from such sites are not necessarily independent, we estimated a minimum number of independent records by including birds from these locations only once in our analysis. Observations of pairs or groups are assigned as single records. These records form the basis for our habitat-use analysis. The influence of the habitat type on Bornean ground-cuckoo and Bornean peacockpheasant distribution was assessed by geo-referencing all independent records and summing their frequency relative to the five habitat types. We used a loglikelihood analysis (G-test) to test for differences in the distribution of records by habitat type and time of year. Expected values were generated based on a random distribution of birds proportional to the amount of each habitat type. To obtain a better approximation to $\chi^{2}$, William's correction to $G$ was applied $\left(G_{\text {adj }}\right.$; Sokal \& Rohlf, 1995). $G_{\text {adj }}$ values were compared with critical values of the $\chi^{2}$ distribution. As we made multiple comparisons, the Bonferonni technique (Sokal \& Rohlf, 1995) was used to limit the overall experiment-wise error, with significance assumed if $\mathrm{P}<0.01$ in a two-tailed test.

Based on data available from congeners (e.g. McGowan, 1992), and to a lesser extent our own observations, we assume both species to be territorial with relative small home ranges. By plotting our records on a topographical map we estimated the minimum number of individuals in our study area. These estimates were extrapolated to the entire Sungai Wain Protection Forest based on the size of our research area in relation to the total area of suitable forest.

\section{Results}

Direct observations of the Bornean ground-cuckoo ranged from $1.5 \mathrm{~h}$ visual contact with calling birds, several sightings on 1 day of two foraging birds following a habituated sun bear, sightings of a bird flying up to a perch at $7 \mathrm{~m}$ height and vocalizing, birds calling from perches in the understorey or on logs, and foraging birds. Observations of the Bornean peacock-pheasant varied from short glimpses of fleeing birds to 10 minuteobservations of a foraging male bird, and lengthy ( $>1 \mathrm{~h}$ ) calling bouts from one location. Overall, however, both species were elusive and in the 44 months in the forest we documented 32 records with Bornean ground-cuckoo (excluding repeated observations over the years near the base-camp) and 19 with Bornean peacock-pheasant. These represented 19 and 13 independent records for Bornean ground-cuckoo and Bornean peacock-pheasant, respectively.

The first Bornean ground-cuckoo was recorded in early 1999 after 14 months in the field, and from then onwards records became more numerous. There was considerable annual variation in monthly encounter rates (1999-2002: Kruskal-Wallis ANOVA, df =3, H = $12.4, \mathrm{P}<0.01)$, and these increased over the course of the study (1997-2002: $\mathrm{R}^{2}=0.99, \mathrm{~F}_{2,3}=456, \mathrm{P}<0.001$; Fig. 2). Bornean ground-cuckoo was sighted 11 times and the remaining 21 records are aural records only. Sightings were more commonly made in the first years of the study as, once we had learned the species' diagnostic vocalizations, not every call was followed by a search to observe the bird (although calling positions were georeferenced). Nineteen birds were sighted, single birds on four occasions, two birds or a pair on six occasions, and three birds on one occasion. Vocalizations were mostly of single birds or a pair, and only once were three birds heard calling simultaneously. Bornean ground-cuckoo was recorded in all months of the year, with the exception of September, with a median of 2 records per month (range 0-6). Separating the year into three 4-month intervals does not reveal any apparent seasonal trend in encounter rate (Kruskal-Wallis ANOVA, $\mathrm{df}=2, \mathrm{H}=0.2$, $\mathrm{P}>0.05)$.

Unlike Bornean ground-cuckoo, Bornean peacockpheasant did not show significant annual variation in monthly encounter rates (1998-2002: Kruskal-Wallis ANOVA, $\mathrm{df}=4, \mathrm{H}=8.4, \mathrm{P}>0.05)$. We recorded the species more regularly in the later stages of our study, 


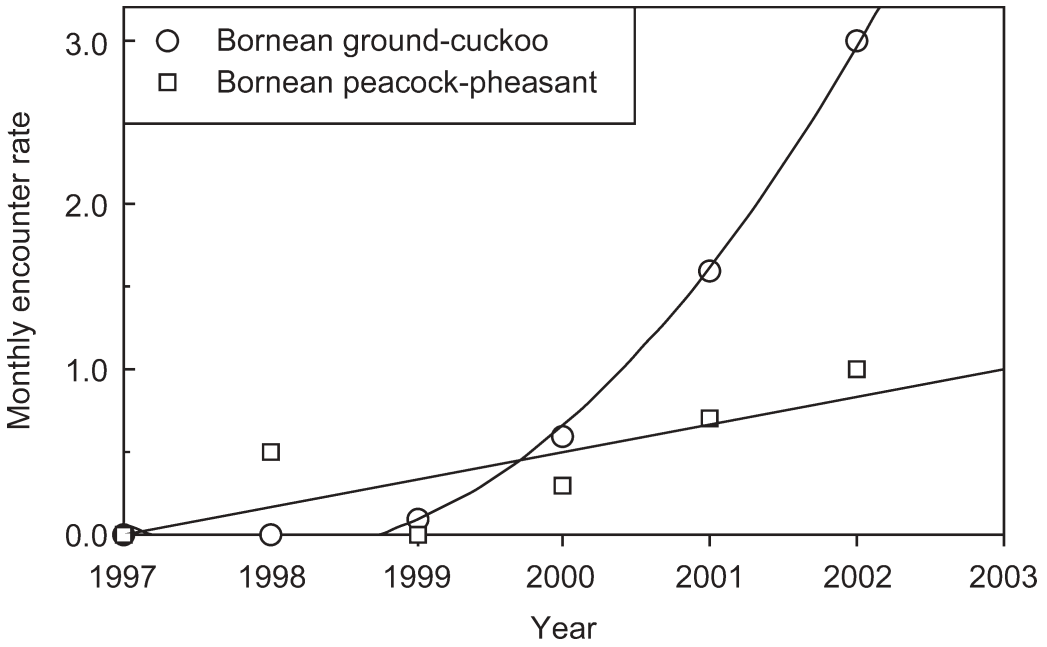

Fig. 2 Monthly encounter rates with Bornean ground-cuckoo Carpococcyx radiatus and Bornean peacock-pheasant Polyplectron schleiermacheri showing an exponential increase over the course of the study for the ground-cuckoo and a slow increase for the peacock-pheasant. but because of the sighting of a single bird three times in March 1998 the increase in monthly encounter rates is not significant (1997-2002: $\mathrm{R}^{2}=0.63, \mathrm{~F}_{2,3}=6.8, \mathrm{P}=0.06$; Fig. 2). Seven birds were sighted, all of them single individuals, and one dead male was found that had been killed, probably by a civet (Viverridae). The remaining 11 records were aural records only. Like the Bornean ground-cuckoo, records were mostly individual birds and we have no records of more than one bird vocalizing at a time. Bornean peacock-pheasant was recorded during 8 months of the year; we did not record it in the months of June and August-October. Median encounter rate was 1 bird per month (range $0-5$ ), and there were no apparent seasonal trends (Kruskal-Wallis ANOVA, $\mathrm{df}=2, \mathrm{H}=3.9, \mathrm{P}>0.05)$.

Our study area covered c. $40 \%$ of the unburned forest of the Sungai Wain Protection Forest. The temporal increase in encounters with both species is almost certainly a result of our improved recognition of the species' vocal behaviour and not because of an increase in population numbers. Based on the number of independent records we estimate that 10-20 Bornean ground-cuckoos and 6-9 Bornean peacock-pheasants were present within our study area. Although we do not have data for all parts of the reserve, these figures suggest that the population of both species in the reserve is almost certainly $<100$ individuals.

We only recorded the two species in the unburned core of the reserve. Burned forest was severely burned, with unburned patches remaining only in permanently inundated areas or along small streams (i.e. swamp or alluvial forest). Thirteen such patches (averaging $77 \pm 48 \mathrm{~m}$ across) were recorded along the three $2 \mathrm{~km}$ transects, representing $18 \pm 4 \%$ of the study area.

Records of Bornean ground-cuckoo from four habitat types (swamp and alluvial forest were pooled to avoid too many low expected values) were not equally distributed $(\mathrm{G}=22.2, \mathrm{df}=3, P<0.001$; Table 1$)$, with observations significantly more often in swamp and alluvial forest than in the other three habitat types combined $\left(\mathrm{G}_{\mathrm{adj}}=19.5 \mathrm{df}=1, P<0.001\right)$ and, conversely, less in slope forest $\left(\mathrm{G}_{\mathrm{adj}}=6.8 \mathrm{df}=1, \mathrm{P}<0.01\right)$. Numbers of records in either high-flat or ridge forest compared to the other forest types combined was not significantly different from that expected if the birds showed a uniform distribution $\left(\mathrm{G}_{\mathrm{adj}}<2.7 \mathrm{df}=1, \mathrm{P}>0.10\right)$.

Because there were fewer independent records of Bornean peacock-pheasant than of Bornean groundcuckoo, high-flat and slope forest were pooled, as well as swamp and alluvial forest. Distribution of Bornean peacock-pheasants was not equal over the three habitat types $(\mathrm{G}=6.6, \mathrm{df}=2, \mathrm{P}>0.02)$ but we consider these differences not significant. Compared to the other habitat types combined, more Bornean peacock-pheasants were recorded in ridge forest $\left(\mathrm{G}_{\mathrm{adj}}=5.9, \mathrm{df}=1, \mathrm{P}>0.01\right)$, but again not significantly so. The species was not recorded less in either swamp and alluvial forest or high-flat and slope forest compared to the other forest types combined $\left(\mathrm{G}_{\text {adj }}<2.7, \mathrm{df}=1, \mathrm{P}>0.10\right)$.

Contrasting the two species, the ratio of swamp and alluvial forest records to those in high-flat, slope and

Table 1 Independent records of Bornean ground-cuckoo Carpococcyx radiatus and Bornean peacock-pheasant Polyplectron schleiermacheri in three forest types (see text for futher details) in Sungai Wain Protection Forest, Kalimantan, during 1997-2002.

\begin{tabular}{|c|c|c|}
\hline $\begin{array}{l}\text { Forest type } \\
\text { (\% of total study area) }\end{array}$ & $\begin{array}{l}\text { Bornean } \\
\text { ground-cuckoo } \\
\text { (\% of total) }\end{array}$ & $\begin{array}{l}\text { Bornean } \\
\text { peacock-pheasant } \\
\text { (\% of total) }\end{array}$ \\
\hline Swamp and alluvial (23.2) & $14(74)$ & $2(15)$ \\
\hline High-flat and slope (70.1) & $4(21)$ & $7(54)$ \\
\hline Ridge (6.7) & $1(5)$ & $4(31)$ \\
\hline
\end{tabular}


ridge forest combined is significantly lower for the Bornean peacock-pheasant than for the Bornean groundcuckoo $\left(\chi^{2}=10.5, \mathrm{df}=1, \mathrm{P}<0.01\right)$ and hence habitat-use of the two species appears to differ. This may be related to differences in floristic composition, food availability, or other characteristics associated with these habitat types.

\section{Discussion}

This is the most detailed study to date on the occurrence and habitat use of either the Bornean peacock-pheasant or the Bornean ground-cuckoo. The total number of records is low but still considerably higher than in any previous study. Both species are rarely seen and, islandwide, the total number of recent (1992-2002) localities number only nine and thirteen for Bornean groundcuckoo and Bornean peacock-pheasant, respectively (Collar et al., 2001; Long \& Collar, 2002; S. van Balen, pers. comm; GMF, unpubl. data). From most of these sites, records refer to single calls or sightings, or just collected feathers, and we are not aware of any site other than Sungai Wain Protection Forest where either species is being recorded on a regular basis.

Despite these scant data some initial inferences have been made about the habitat preferences of both species. Long \& Collar (2002), on the basis of tallying the number of records in different habitat types and/or on the basis of locality names, cautiously inferred 'a close ecological link [of Bornean ground-cuckoo] with riverine fringes and flood plains throughout the island'. O'Brien et al. (1998) made inferences about the habitat preferences of the Bornean peacock-pheasant based on data from interviews (for a critique, see Sözer et al. 2000 and Kinnaird \& O'Brien, 2000), and concluded that the species has a preference for primary lowland forest, avoiding swamp and riverine forest. Finally, Collar et al. (2001), again on the basis of tallying records of this species, suspected the Bornean peacock-pheasant to be a bird of the lowland dipterocarp and alluvial forest, with a possible preference for black, more fertile (alluvial) soils. Because all these inferences are based on fragmentary records, they cannot be used to discriminate genuine habitat preferences (cf. Long \& Collar, 2002). This study and the observations of others indicate that both species occur at low densities and are probably restricted to certain habitat types; neither species is likely to be able to persist outside closed forest.

In the Sungai Wain Protection Forest our records are directly linked to one of five habitats, the relative abundance of which was assessed. We found Bornean ground-cuckoo to have a clear preference for swamp and alluvial forest, and Bornean peacock-pheasant, albeit less clear-cut, for ridge forest. Selection of which habitat types to include in the analysis can have an effect on its conclusions, especially when types are included where the species of interest is never or rarely recorded (Nijman, 1998). In our study, we only included habitat types that both species were known to use, and we believe that the recorded patterns are a true reflection of their habitat use. We stress, however, that all our topographical forest types refer to what is normally defined as dry lowland dipterocarp forest (Whitmore, 1985). Thus swamp forest refers to swampy patches within the drier forest and has no direct relation to large areas of peat or freshwater swamp forest as found in, for example, south-central Borneo. Likewise, ridge forest has no direct relation with hill or montane forests as found in Borneo's interior.

Long \& Collar (2002) tentatively identified the period February-July as the egg-laying period of the Bornean ground-cuckoo. No inconclusive data on breeding of Bornean peacock-pheasant is available from the wild. We found no apparent seasonality in calling behaviour of either species. Throughout the year several observations of Bornean ground-cuckoos were made of two birds calling for prolonged periods of time (up to $1.5 \mathrm{~h}$ ), and contrary to Long \& Collar (2002) no conclusions can be made of their relationship to a defined breeding period or clear courtship activities. S. van Balen (unpub. data) recorded the Bornean peacock-pheasant's call in 2 of the 4 months in which we did not record it (viz. June and October), further suggesting that there is no seasonality in the calling behaviour of this species.

During the last two decades uncontrolled fires damaged vast tracts of forest in Indonesia (Siegert et al., 2001). The drought of 1997-1998 was so severe that primary forest areas burned readily, with $74 \pm 9 \%$ of trees ( $\geq 10 \mathrm{~cm}$ diameter at breast height) dead 21 months after the fire event in the Sungai Wain Protection Forest (van Nieuwstadt, 2002). Fire damage in primary forest was not evenly distributed, with many small swamp and alluvial areas escaping damage, remaining as primary forest islands in a matrix of burned forest. All available data indicate that both Bornean ground-cuckoo and Bornean peacock-pheasant are birds of closed forest. The Bornean ground-cuckoo shows a clear preference for swamp and alluvial forest and, as indicated above, these topographical forest types are less affected by forest fires than the other forest types. Therefore it is possible that this species has not been affected by the fires to the same extent as the Bornean peacock-pheasant. However, 4 years after the 1997-1998 forest fires both species have been recorded in burned forest $20-30 \mathrm{~km}$ north of our study area (S. van Balen, pers comm), despite the fact that during our extensive fieldwork in burned forest neither 
species was ever heard or seen in such areas. Surveys to determine whether the two species are able to persist in burned regenerating forest could make use of the fact that both species respond to play-back recordings (B. King, pers. obs.).

Management of most protected areas in Kalimantan is at best limited to signboards erected along a designated border. Law enforcement or active protection measures such as patrols, and arrests of illegal loggers or hunters, are rare (Rijksen \& Meijaard, 1999; Jepson et al., 2001). Hunting with snares of ground-dwelling birds is a common activity in virtually all accessible forest areas in Kalimantan and both the Bornean ground-cuckoo and Bornean peacock-pheasant are regularly trapped ( $R$. Sözer, pers comm; Long \& Collar, 2002). In general, there is a high extinction risk for species in Kalimantan that are restricted mainly to lowland forest and live at low densities, faced as they are by rampant logging, recurrent fires, increased hunting pressure and lack of management of most protected areas.

The Sungai Wain Protection Forest is surrounded mostly by grasslands and is isolated from other smaller, unburned areas of primary forest. As both the Bornean ground-cuckoo and the Bornean peacock-pheasant are bound by their ecology to closed forest, dispersal by either species to other forest areas is unlikely. Hence the survival of these populations depends on continued preservation of the Sungai Wain Protection Forest, and possibly smaller patches of forest in the region.

Although patrolling of protected areas on a permanent basis is generally uncommon in Indonesia (Rijksen \& Meijaard, 1999), teams of police, army and local staff, operating in rotating mixed groups to avoid internal collusion, carry out daily patrols to prevent hunting and illegal logging in the Sungai Wain Protection Forest. In addition, following a government decree, all commercially valuable trees surrounding the core of the reserve have been spiked with 6 inch steel nails. As a result of these activities illegal hunting and logging have come to an almost complete halt. Awareness and education work have also been continuing for several years and a multistakeholder management board has been set up, with the local government providing substantial funds. Regeneration of burned areas may result in an increase of suitable habitat for the Bornean ground-cuckoo and the Bornean peacock-pheasant, and also for other forest species. The example of the Sungai Wain Protection Forest shows that such reserves can be successfully maintained, although continued vigilance for major fires is required.

\section{Acknowledgements}

We are grateful to the Indonesian Institute of Sciences for permitting us to do field research. Financial support for field work was received from Martina de Beukelaar
Foundation, J.C. van der Hucht Fund, and Tropenbos Foundation. For useful comments we thank S. van Balen, R. Sözer, G. Usher, J.M. Lammertink and S.B.J. Menken.

\section{References}

Bibby, C.J., Burgess, N.D. \& Hill, D.A. (1992) Bird Census Techniques. Academic Press, London, UK.

Collar, N.J., Andreev, J.V., Chan, S., Crosby, M.J., Subramanya, S. \& Tobias, J.A. (eds) (2001) Threatened Birds of Asia. BirdLife International, Cambridge, UK.

Fredriksson, G.M. (2002) Extinguishing the 1998 forest fires and subsequent coal fires in the Sungai Wain Protection Forest, East Kalimantan, Indonesia. In Communities in Flames (eds P. Moore, D. Ganz, L.C. Tan, T. Enters \& P.B. Durst), pp. 74-80. Food and Agriculture Organization, Bangkok, Thailand.

Fredriksson, G.M. \& de Kam, M. (1999) Strategic Plan for the Conservation of the Sungai Wain Protection Forest, East Kalimantan, Indonesia, Tropenbos Kalimantan, Balikpapan, Indonesia.

Holmes, D.A. \& Burton, K. (1987) Recent notes on the avifauna of Kalimantan. Kukila, 3, 2-32.

IUCN (2003) 2003 IUCN Red List of Threatened Species. IUCN, Gland, Switzerland [http:/ / www.redlist.org, accessed 29 April 2004].

Jepson, P., Jarvie, J.K., MacKinnon, K. \& Monk, K.A. (2001) The end of Indonesia's lowland forests? Science, 292, 859-861.

Kinnaird, M. \& O'Brien, T. (2000) Local knowledge of the Bornean peacock-pheasant: a reply to Sözer et al. (2000). Bird Conservation International, 10, 317-318.

Laman, T.G., Burnaford, J.L. \& Knott, C.D. (1997) Bornean ground-cuckoo observations in Gunung Palung National Park, West Kalimantan. Kukila, 9, 183-184.

Long, A.J. \& Collar, N.J. (2002) Distribution, status and natural history of the Bornean Ground-cuckoo Carpococcyx radiatus. Forktail, 18, 111-119.

McGowan, P.J.K. (1992) Social organisation in the Malaysian peacock pheasant. PhD thesis, Open University, UK.

Nijman, V. (1998) Habitat preference of great argus pheasant (Argusianus argus) in Kayan Mentarang National Park, East Kalimantan, Indonesia. Journal für Ornithologie, 139, 313-323.

O'Brien, T., Winarni, N.L., Saanin, F.M., Kinnaird, M. \& Jepson, P. (1998) Distribution and conservation status of Bornean Peacock-pheasant Polyplectron schleiermacheri in Central Kalimantan, Indonesia. Bird Conservation International, 9, 373-385.

Rijksen, H.D. \& Meijaard E. (1999) Our Vanishing Relative. Kluwer Academic Publishers, Dordrecht, The Netherlands.

Siegel, S. (1956) Nonparametric Statistics for the Behavioral Sciences. McGraw-Hill, Auckland, New Zealand.

Siegert, F., Ruecker, G., Hinrichs, A. \& Hoffmann, A.A. (2001) Increased damage from fires in logged forests during droughts caused by El Niño. Nature, 414, 437-440.

Sokal, R.R. \& Rohlf, F.J. (1995) Biometry. 3rd Edition. W.H. Freeman, New York, USA.

Sözer, R., Setiawan, I. \& Setiadi, A.P. (2000) Local knowledge of the Bornean Peacock-pheasant Polyplectron schleiermacheri: a critique of O'Brien et al. (1998a) Bird Conservation International, 10, 311-316.

van Nieuwstadt, M.G.L. (2002) Trial by fire. PhD thesis, Utrecht University, The Netherlands.

Whitmore, T.C. (1985) Tropical Rainforests of the Far East. Clarendon Press, Oxford, UK. 


\section{Biographical sketches}

Gabriella Fredriksson has worked in Indonesia since 1994, initially on orang-utans but later on Malayan sun bears and is co-chair of the IUCN/Species Survival Commission sun bear expert team. She is now focusing on protected area management in Kalimantan.

Vincent Nijman studied the ecology and conservation of Sundaic primates, and since 1994 he has been conducting research on birds and primates in Indonesia and has been active in implementing conservation activities in Java. 